\title{
JUURNAL.RU
}

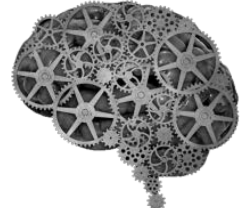

COMPANY GROUP "INTELLEKT"

\author{
Будникова Ю.Е. \\ Институт государства и права РАН \\ Москва, Россия
}

doi: 10.18411/lj2016-8-2-02

idsp 000001: lj2016-17-2-02

\section{Инновационное развитие правового механизма в сфере предпринимательства, основанного на использовании природных ресурсов}

Сегодня, как в научной среде, так и на государственном уровне, очень много говорится, о необходимости создания качественно новых подходов к регулированию современных проблем в экономике. В настоящее время экономические факторы, складывающиеся под воздействием мировых геополитических явлений, оказывают колоссальное влияние на развитие правовой системы России.

В связи с чем, задача предпринимательского права в настоящее время заключается в его инновационном развитии, нахождении новых путей совершенствования правового регулирования предпринимательской деятельности, создании иного правового механизма в предпринимательской cфepe.

В условиях взятого курса на импортозамещение и ухода от сложившейся десятилетиями экспортно-сырьевой модели экономики, возникает потребность в активном поиске новых решений, новых методов государственного регулирования предпринимательства и т.д.

При этом, несмотря на активную законотворческую деятельность, до сих пор в России отсутствует единый законодательный акт, из которого можно было бы получить общее представление о государственном регулировании всех отраслей экономики. Конечно отдельные элементы такого регулирования разбросаны по ряду федеральных законов и множеству подзаконного нормативного материала. Однако в современных условиях в нашей стране важно 
законодательно определить формы и методы государственного регулирования предпринимательской деятельности.

Особенно реальное значение сегодня имеет совершенствование правового механизма некоторых институтов государственного регулирования экономики. Это относится, например, к планированию в области использования и воспроизводства природных ресурсов.

Сегодня Россия является одним из мировых лидеров по запасам, добыче и экспорту нефти, природного газа, углей, железных руд, никеля, платиноидов, золота, алмазов, фосфатов и многих других полезных ископаемых.

По мнению государственных органов, обеспечение рационального использования и воспроизводства природных ресурсов является одним из ключевых общественных благ, которые формируют основу долгосрочного социально-экономического развития, обусловливают материальную базу развития будущих поколений.

Однако анализ действующего правового регулирования отношений по использованию природных ресурсов в предпринимательских целях показывает несогласованность и разрозненность норм, регламентирующих данные общественные отношения.

Законодательство в сфере использования природных ресурсов сводится исключительно к охране природных компонентов, тогда как имущественные отношения, связанные с оборотом природных объектов, регулируются гражданским законодательством. Но если не касаться охраны природных объектов, возникает вопрос, каким образом частноправовые нормы могут обеспечить результативное правовое воздействие на публичные отношения.

Однако проблема заключается даже не в том, что распоряжение природными ресурсами регламентируется частноправовыми положениями. В условиях рыночной экономики, основанной на частном капитале, ее эффективное регулирование может быть обеспечено только на основе сочетания частноправовых и публично-правовых начал. Главный вопрос здесь заключается в разумном соотношении государственного влияния на предпринимательскую деятельность и саморегулирования в данной сфере.

Очевидно, что в сфере использования национальных природных богатств роль государства в процессе осуществления предпринимательской деятельности 
особенно важна, т.к. речь идет о стратегических ресурсах страны. И их использование должно осуществляться исключительно под контролем государства. Поскольку только государство заинтересовано в обеспечении рационального использования и воспроизводства природных ресурсов, которые формируют основу долгосрочного социально-экономического развития России. Невозможно добиться высоких экономических показателей без точного планирования использования природных ресурсов. В свою очередь интересы частного бизнес не всегда совпадают с общественным благом.

Разумеется, что курс взятый на инновации и модернизацию экономику сопровождается принятием огромного количества нормативных актов, закрепляющих, развивающих и уточняющих целевые установки.

Примером может служить недавно принятый Федеральный закон от 31.12.14 г. № 488-Ф3 "О промышленной политике в Российской Федерации". Данный закон является ярким образцом рамочного, отсылочного закона, который ничего конкретно не регламентирует, а только ссылается на иные законодательные акты в различных отраслях экономики и состоит всего из 23 статей. Многие положения, которого к тому же носят сугубо декларативный характер, вместе с которым потребуется внесения многочисленных изменений и дополнений в подзаконные акты, а также принятия новых нормативных правовых актов различного уровня.

Однако задача на современном этапе заключается не в том, чтобы хаотично реформировать законодательство в области предпринимательства, которое начнет кардинально и спешно обновлять устоявшиеся правовые положения, как например это происходило с гражданским законодательством.

Не такие правовые средства, как указанный выше закон, требуются сегодня для решения серьезных экономических проблем. При сложно выстроенных взаимоотношениях государства и субъектов предпринимательства различного уровня необходим адекватный, грамотный правовой механизм в сфере осуществления предпринимательской деятельности.

Совершенствование законодательства должно быть разумным, взвешенным, требующее непрерывного научного анализа и основываться на многолетних фундаментальных научных исследованиях. Система 
правотворчества должна быть выстроена надлежащим образом и являться целостной и сбалансированной.

В этом смысле особенно важно создание базового, межотраслевого, комплексного законодательного акта, формирующего основы национальной политики в области предпринимательства. В котором, должны быть определены формы и методы государственного регулирования предпринимательской (хозяйственной) деятельности, адекватно урегулированы полномочия органов государственной власти, созданы формы и условия государственной поддержки, установлены антикризисные положения и т.д.

В том числе в указанном законе следует уделить внимание государственному регулированию предпринимательской деятельности, основанной на использовании природных ресурсах. Поскольку такой вид деятельности охватывает весь реальный сектор экономики.

В контексте данного закона под предпринимательской деятельностью, связанной с использованием природных ресурсов следует понимать разновидность предпринимательства, подчиняющуюся специальному (или особому) правовому режиму, в силу которого свобода предпринимательской деятельности ограничена производностью права пользования природными ресурсами от права собственности на них государства и целевым назначением использования природных ресурсов, получение прибыли как основная цель бизнеса корреспондирует рациональному природопользованию и экосистемному подходу, предпринимательский риск снижен за счет устойчивости права пользования природными ресурсами, а плата за пользование сочетается с ответственностью предпринимателя за нарушение природоохранных норм.

При этом, по степени воздействия на окружающую природную среду предпринимательская деятельность, основанная на использовании природных ресурсов, подразделяется на две категории, первая из которых связана с прямым использованием природных ресурсов, а вторая - с косвенным.

Это означает, что в процессе хозяйственной деятельности природные ресурсы используются как напрямую, т.е. в качестве основного средства для извлечения прибыли так и опосредованно, оказывая негативное воздействие на природный объект, либо на всю окружающую природную среду. 
Непосредственная эксплуатация подразумевает под собой извлечение природных ресурсов и вовлечение их в хозяйственный оборот в качестве предмета получения прибыли. Существуют такие виды деятельности как, например, добыча минерального сырья, других полезных ископаемых, использование водных ресурсов, включая подземные воды, заготовка древесины, заготовка пищевых лесных ресурсов и сбор лекарственных растений, рыболовство, добыча объектов животного мира и т.д. Это означает, что предпринимательская деятельность связана непосредственно с изъятием какоголибо природного объекта из экосистемы, для получения прибыли от реализации этих природных ресурсов, так называемая природоэксплуатирующая деятельность.

Наряду с этим возможно и косвенное использование природных объектов, например, использование водных объектов для производства электрической энергии, инженерно-геологические изыскания, строительство и эксплуатация подземных сооружений, которые влекут за собой физическое нарушение почвенно-растительного покрова, грунтов, природных ландшафтов, в северных регионах - нарушение естественного режима многолетнемерзлых грунтов, а также осуществление рекреационной деятельности, где природная среда является только местом предпринимательской деятельности и т.д. Т.е. когда хозяйственная деятельность не приносит доход от реализации природного pecypca, но косвенно воздействует на состояние природного объекта и окружающей среды в целом.

Опосредованное использование природных ресурсов предполагается путем внедрения в природную среду без вовлечения их в хозяйственный оборот, но оказывая влияние на состояние окружающей среды.

Необходимо отметить, что правовое регулирование данных категорий предпринимательства распадается на законодательство о предпринимательстве и природоресурсное законодательство, что предопределяет разобщенность правовых основ такого предпринимательства. Между тем, комплексный подход к нему необходим уже по той причине, что потребляющий природные ресурсы бизнес требует особых доктринальных подходов и специального регулирования. 
Указанный выше закон также может послужить правовым гарантом разработки и реализации способов внедрения принципа рационального природопользования при осуществлении хозяйственной деятельности.

Подводя итог, следует согласиться с Н.И. Михайловым, в том, что формирование правовой системы современной России все еще продолжается и нам предстоит еще очень много работы в этом направлении. 


\section{Литература:}

1. URL: http://www.mnr.gov.ru. Доклад Министерства природных ресурсов и экологии Российской Федерации о результатах и основных направлениях деятельности на 2008 - 2010 гг.

2. См.: Михайлов Н.И. Влияние на экономику страны предпринимательского права через науку и учебный процесс // Право и бизнес. Приложение к журналу «Предпринимательское право». 2016. № 1. С.17. 